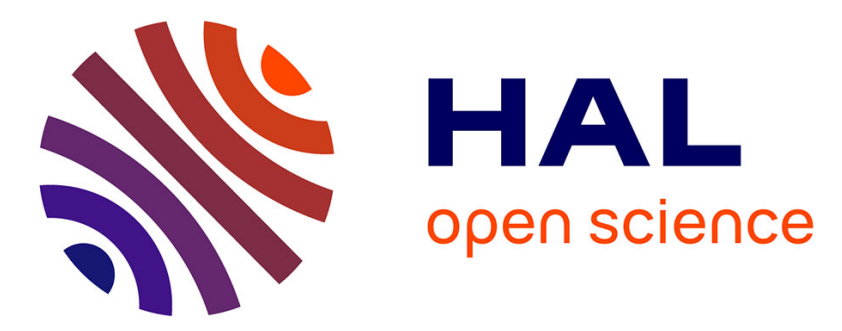

\title{
One-step synthesis of conjugated enynenitriles from bromocyanoacetylene
}

\author{
Romain Ligny, Etienne S. Gauthier, Manuel Yanez, Thierry Roisnel, \\ Jean-Claude Guillemin, Yann Trolez
}

\section{- To cite this version:}

Romain Ligny, Etienne S. Gauthier, Manuel Yanez, Thierry Roisnel, Jean-Claude Guillemin, et al.. One-step synthesis of conjugated enynenitriles from bromocyanoacetylene. Organic \& Biomolecular Chemistry, 2017, 15 (28), pp.6050-6056. 10.1039/c6ob02590k . hal-01578550

\section{HAL Id: hal-01578550 \\ https://hal-univ-rennes1.archives-ouvertes.fr/hal-01578550}

Submitted on 13 Sep 2017

HAL is a multi-disciplinary open access archive for the deposit and dissemination of scientific research documents, whether they are published or not. The documents may come from teaching and research institutions in France or abroad, or from public or private research centers.
L'archive ouverte pluridisciplinaire HAL, est destinée au dépôt et à la diffusion de documents scientifiques de niveau recherche, publiés ou non, émanant des établissements d'enseignement et de recherche français ou étrangers, des laboratoires publics ou privés. 


\title{
One-step synthesis of conjugated enynenitriles from bromocyanoacetylene
}

\author{
Romain Ligny, ${ }^{a}$ Etienne S. Gauthier, ${ }^{a}$ Manuel Yáñez, ${ }^{b}$ Thierry Roisnel, ${ }^{c}$ Jean-Claude \\ Guillemin, ${ }^{a}$ Yann Trolez ${ }^{\text {a* }}$
}

a Ecole Nationale Supérieure de Chimie de Rennes, UMR 6226, CNRS, 11 allée de Beaulieu, CS 50837, 35708 Rennes Cedex 7, France. Tel: 332232380 69; E-mail: yann.trolez@enscrennes.fr

b Departamento de Química, Módulo 13, Universidad Autónoma de Madrid, Campus de Excelencia UAM-CSIC, Cantoblanco, 28049 Madrid, Spain

${ }^{\mathrm{C}}$ Centre de Diffractométrie $X$, Institut des Sciences Chimiques de Rennes, CNRS (UMR 6226), Université de Rennes 1, Campus de Beaulieu, 35042 Rennes Cedex, France

† Electronic supplementary information (ESI) available: Experimental data and NMR spectra. See DOI:

Table of content
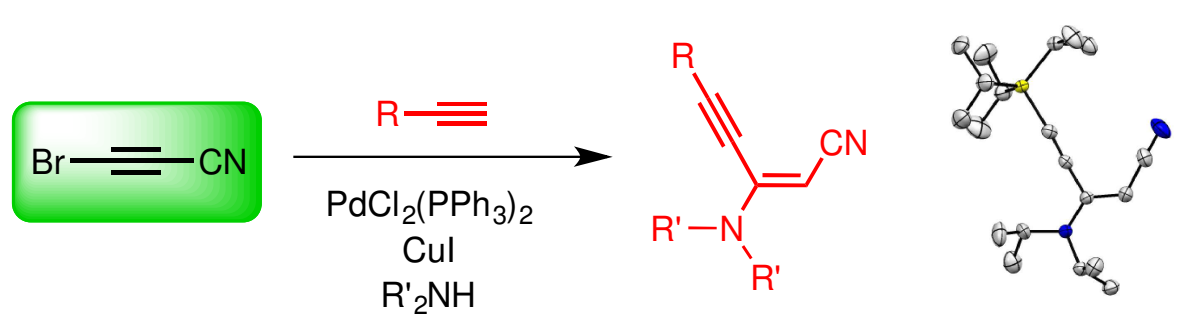

Bromocyanoacetylene is able to provide conjugated enynenitriles stereoselectively in one step from alkynes, secondary amines and co-catalysts.

The chemical reactivity of bromocyanoacetylene has been evaluated for the first time by making it react with terminal alkynes and secondary amines in the presence of bis(triphenylphosphine)palladium dichloride and copper iodide as co-catalysts. This reaction provided new conjugated enynenitriles stereoselectively in one step in variable yields.

The synthesis of 1,3-enynes is of particular interest in different fields such as biology, electronics and photonics. ${ }^{1}$ Numerous recent publications report new ways to overcome the problem of synthesizing 1,3-enynes in a controlled manner, especially concerning the configuration of the $\mathrm{C}=\mathrm{C}$ double bond. ${ }^{2}$ In most cases, the synthesis of 1,3 -enynes proceeds in two steps by first forming a functionalized alkene having the desired configuration and then coupling a terminal alkyne following a Sonogashira or a Negishi-like coupling. ${ }^{3}$ Alternatively, the addition of the alkyne may be performed first and the $\mathrm{C}=\mathrm{C}$ double bond is formed subsequently. ${ }^{4}$ More rarely, we can find in the literature elegant methods using a one-pot procedure for the formation of the alkene and the addition of the alkyne ${ }^{5}$ or direct formation of the 1,3-enyne by alkyne cross-coupling. ${ }^{6}$

Our laboratory recently reported on the particular reactivity of bromocyanobutadiyne $\mathrm{BrC}_{5} \mathrm{~N} \mathbf{1}$ with triisopropylsilylacetylene in the presence of palladium(II) complexes and copper(I) as co-catalysts, as well as diisopropylamine. We showed the formation of an unexpected dienyne in a stereoselective fashion (Scheme 1a). ${ }^{7}$ Inspired by this work, we wondered whether the smaller homologous counterpart 
bromocyanoacetylene $\mathrm{BrC}_{3} \mathrm{~N} 2$ could react the same way or would lead to a more standard reactivity such as a Cadiot-Chodkiewicz coupling as does the corresponding ester. ${ }^{8}$ If the reactivity would be the same as $\mathrm{BrC}_{5} \mathrm{~N}, \mathrm{BrC}_{3} \mathrm{~N}$ should be a precursor of conjugated enynenitriles (Scheme 1b). Surprisingly, to the best of our knowledge, the chemical reactivity of $\mathrm{BrC}_{3} \mathrm{~N}$ in solution has never been investigated whereas its halogen-free counterpart $\mathrm{HC}_{3} \mathrm{~N}$ has largely been documented. ${ }^{9}$

In this article, we report the stereoselective synthesis of conjugated enynenitriles in moderate to good yields in one step from $\mathrm{BrC}_{3} \mathrm{~N}$, a terminal alkyne and an amine using bis(triphenylphosphine)palladium dichloride and copper iodide as co-catalysts.

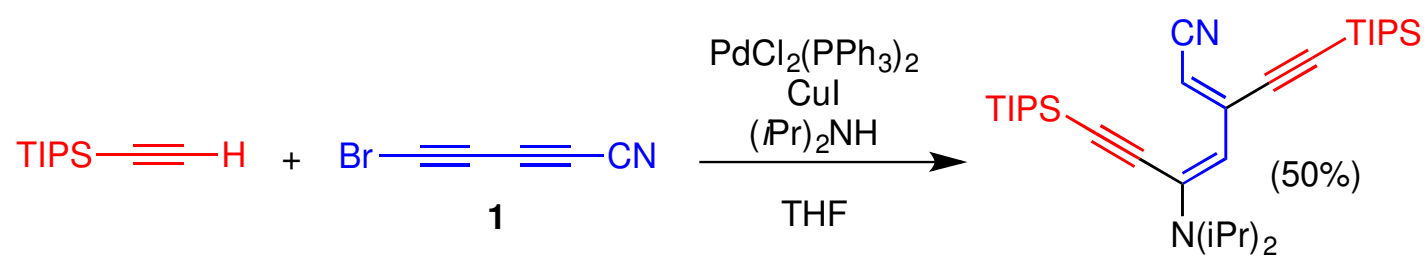

a) Previous work.

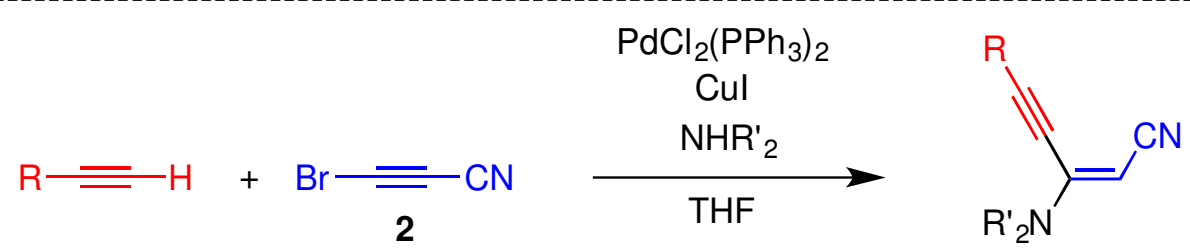

b) This work.

Scheme 1 a) Previous work: reactivity of $\mathrm{BrC}_{5} \mathrm{~N}$; b) This work: reactivity of $\mathrm{BrC}_{3} \mathrm{~N}$.

First, the reactivity of $\mathrm{BrC}_{3} \mathrm{~N}$, which was synthesized according to a described procedure, ${ }^{10}$ was evaluated with different amines (5 equiv) and phenylacetylene ( 2 equiv). Bis(triphenylphosphine)palladium dichloride (10 mol\%) and copper iodide (10 mol\%) were used as co-catalysts and the reaction was run each time in THF overnight at room temperature under inert atmosphere. Four amines were tested: the reaction only led to degradation with morpholine or dibenzylamine, but enynenitriles 5, 6 and $\mathbf{7}$ were obtained in $34 \%$ yield with diethylamine, $82 \%$ yield with diisopropylamine and $42 \%$ yield with diethylbenzylamine (Table 1). The E-configuration of the CC double bond was clearly established by 2D-NMR spectroscopy and no traces of the Z-isomer could be observed.

The fact that the reaction did not work with morpholine could be explained by a stronger nucleophilicity that would imply potential multiple additions on $\mathrm{BrC}_{3} \mathrm{~N}$ before phenylacetylene could react. ${ }^{11}$ Concerning dibenzylamine, the reasons are more obscure. Steric hindrance cannot be invoked since enynenitrile 7 could be obtained with diethylbenzylamine. Given these five results, diisopropylamine was chosen to evaluate the scope of this reaction with different alkynes. 
Table 1 Formation of enynenitriles with different amines. ${ }^{a}$

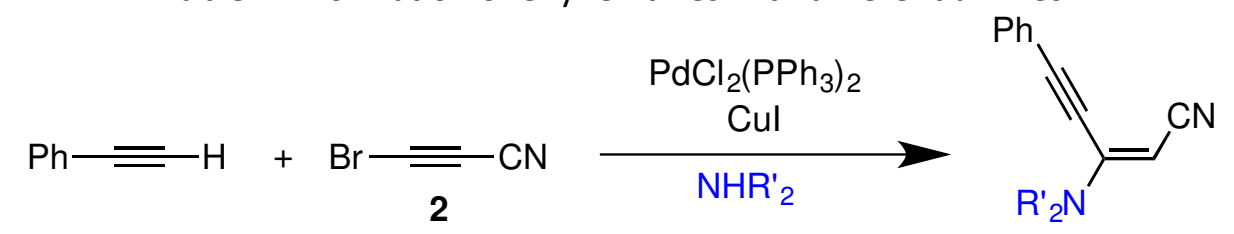

\begin{tabular}{|c|c|c|c|}
\hline Entry & $\mathrm{NHR}_{2}$ & Product & Yield $^{\mathrm{b}}$ \\
\hline 1 & & 3 & $0 \%$ \\
\hline 2 & $\mathrm{Ph} \widehat{\mathrm{N}_{\mathrm{H}}^{\mathrm{N}}} \widehat{\mathrm{Ph}}$ & 4 & $0 \%$ \\
\hline 3 & 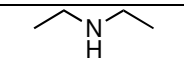 & 5 & $34 \%$ \\
\hline 4 & & 6 & $82 \%$ \\
\hline 5 & & 7 & $42 \%$ \\
\hline
\end{tabular}

${ }^{a}$ Reaction conditions: bromocyanoacetylene (0.2 M in THF), phenylacetylene (2 equiv. vs. $\mathrm{BrC}_{3} \mathrm{~N}$ ), $\mathrm{PdCl}_{2}\left(\mathrm{PPh}_{3}\right)_{2}$ (0.1 equiv. vs. $\left.\mathrm{BrC}_{3} \mathrm{~N}\right)$, Cul (0.1 equiv. vs. $\mathrm{BrC}_{3} \mathrm{~N}$ ), $\mathrm{NHR}_{2}^{\prime}$ (5 equiv. vs. $\left.\mathrm{BrC}_{3} \mathrm{~N}\right)$, r.t., $17 \mathrm{~h} .{ }^{\mathrm{b}}$ Isolated yield.

In the same conditions as previously described, the reactivity of $\mathrm{BrC}_{3} \mathrm{~N}$ was evaluated by reacting it with different terminal alkynes (scheme 2). Using trimethylsilylacetylene instead of phenylacetylene slightly lowers the yield to $60 \%$ (compound 8 ). However, the use of triethylsilylacetylene or triisopropylsilylacetylene dramatically affects the reaction and leads to the corresponding enynes in 25 and 23\% yield respectively (compounds 9 and 10). Steric hindrance is probably responsible for this drop of yield. This interpretation is confirmed by using 2,4,6-trimethylphenylacetylene that completely inhibits the reaction (compound 15). Moreover, when using triisopropylsilylbutadiyne, the obtained yield is $75 \%$ (compound 11), which confirms that taking away a bulky group is better for the reaction. The use of 1-octyne and para-methylphenylacetylene leads to the corresponding products 12 and 14 in acceptable yields of 55 and $57 \%$ respectively, whereas only traces of enyne 13 were obtained from 2-methyl-but-3-yn-2-ol. It is important to notice that all the indicated yields were calculated from products isolated after column chromatography. When using para-cyanophenylacetylene, no corresponding enyne $\mathbf{1 6}$ could be obtained but only an insoluble product was isolated which structure was assigned to the product of homocoupling of the terminal acetylene (Glaser-type coupling) according to ${ }^{1} \mathrm{H}-\mathrm{NMR}$ spectroscopy. ${ }^{12}$ Nevertheless, electron-deficient alkynes are not prohibited since paramethylbenzoateacetylene and para-trifluoromethylphenylacetylene led to enynes $\mathbf{1 7}$ and $\mathbf{1 8}$ in 55 and $82 \%$ yields, respectively. Concerning electron-rich alkynes, no enyne could be isolated from the reaction with 4-ethynyl- $\mathrm{N}, \mathrm{N}$-dimethylbenzenamine. However, enynes 20, $\mathbf{2 1}$ and $\mathbf{2 2}$ were obtained from the corresponding ynamide ${ }^{13}$, para-methoxyphenylacetylene and ethynylferrocene in 23, 66 and $80 \%$ yields respectively. Interestingly, when using a reactant bearing two terminal acetylenes separated by a biphenyl unit, ${ }^{14}$ only one CC triple bond reacted to afford compound 23 in $44 \%$ yield. This observation opens possibilities to further functionalize this kind of compounds. 


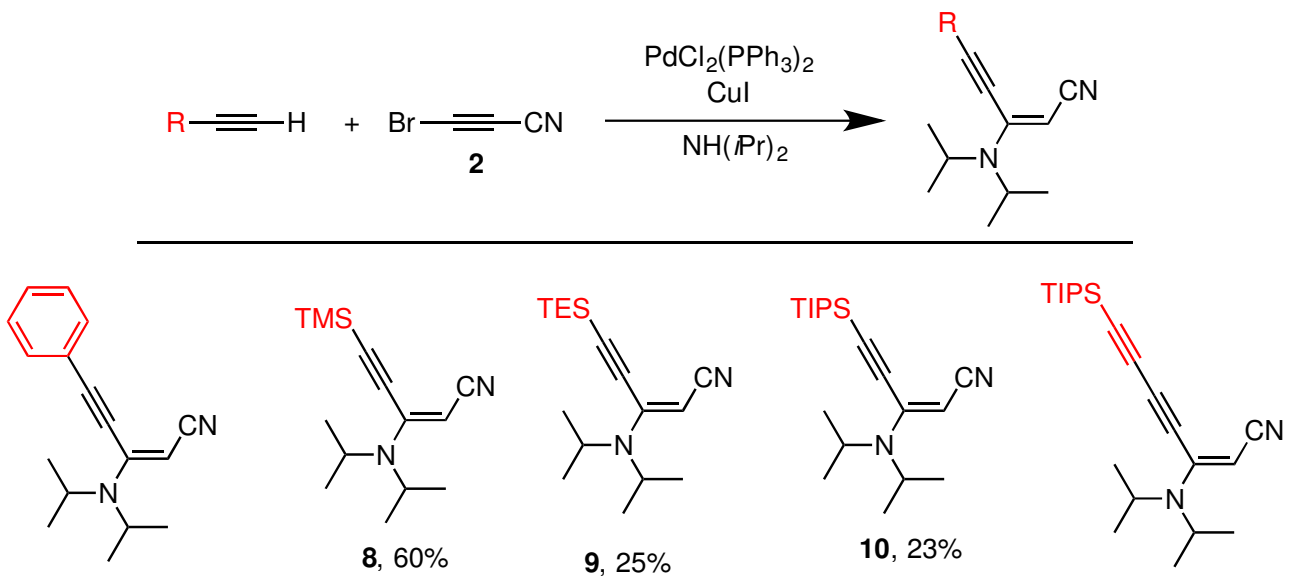

6, $82 \%$

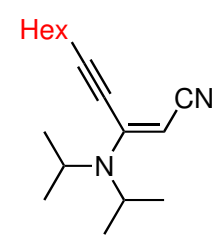

12, $55 \%$

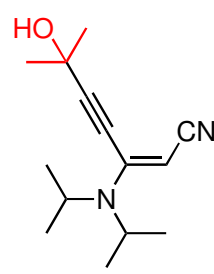

13, traces

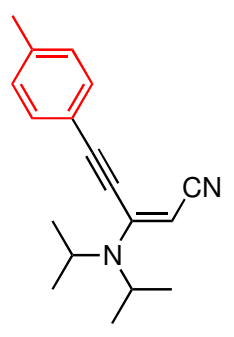

$14,57 \%$

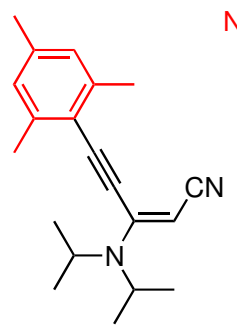

15, $0 \%$

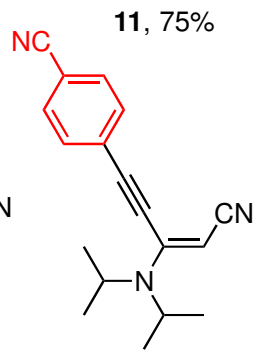

16, $0 \%$

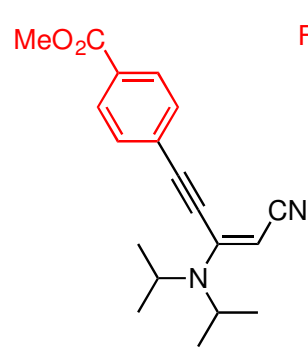

17, $55 \%$

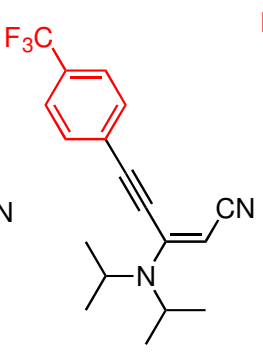

$18,82 \%$

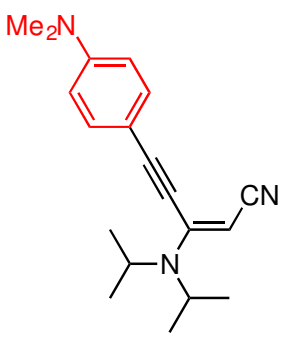

19, $0 \%$

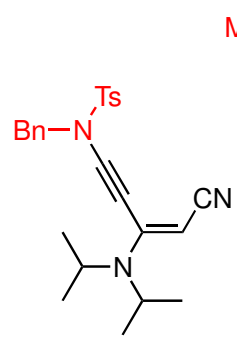

20, $23 \%$

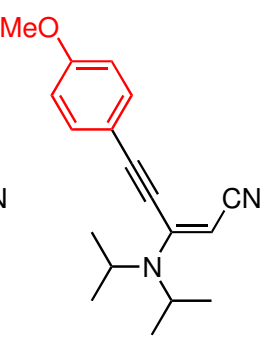

21, $66 \%$

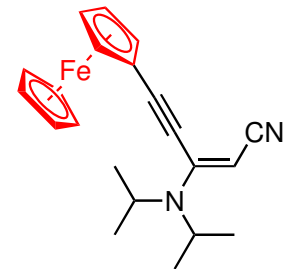

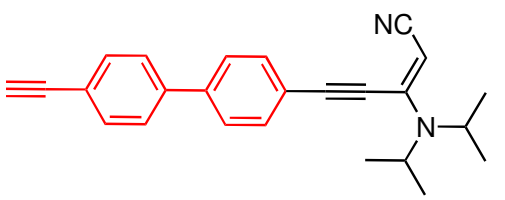

23, $44 \%$

22, $80 \%$

Scheme 2 Reactivity of $\mathrm{BrC}_{3} \mathrm{~N}$ using different terminal alkynes. Reaction conditions: bromocyanoacetylene (0.2 $\mathrm{M}$ in THF), alkyne (2 equiv. vs. $\left.\mathrm{BrC}_{3} \mathrm{~N}\right), \mathrm{PdCl}_{2}\left(\mathrm{PPh}_{3}\right)_{2}\left(0.1\right.$ equiv. vs. $\left.\mathrm{BrC}_{3} \mathrm{~N}\right)$, Cul (0.1 equiv. vs. $\left.\mathrm{BrC}_{3} \mathrm{~N}\right)$, diisopropylamine (5 equiv. vs. $\left.\mathrm{BrC}_{3} \mathrm{~N}\right)$, r.t., $17 \mathrm{~h}$.

The reactivity of enyne $\mathbf{1 0}$ was evaluated by a one-pot deprotection-Eglington coupling reaction in the presence of TBAF and $\mathrm{Cu}(\mathrm{OAc})_{2}$ in a mixture pyridine and diethyl ether leading to diyne $\mathbf{2 4}$ in $\mathbf{1 0 \%}$ yield (scheme 3 ). Despite the very modest yield obtained for this sequence, it shows the possibility these enynes may offer in the future for diverse applications such as the construction of $\pi$-conjugated systems. ${ }^{15}$ 

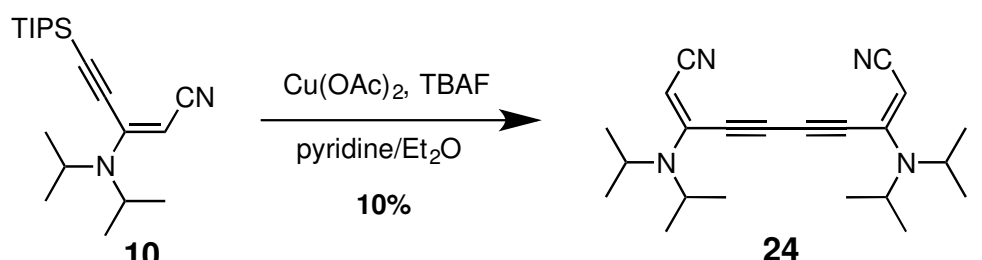

Scheme 3 Synthesis of diyne $\mathbf{2 4}$ from enyne $\mathbf{1 0}$

Crystals suitable for X-ray diffraction were obtained for compounds $\mathbf{2}$ and $\mathbf{1 0}$ (Figure 1). The structure of compound $\mathbf{2}$ shows a particularly short $C-C$ single bond ( $1.38 \AA$ ), showing thus a significant double bond character. This is most probably due to the conjugation of the $\mathrm{C} \equiv \mathrm{C}$ and the $\mathrm{C} \equiv \mathrm{N}$ triple bonds. ${ }^{16}$ The other distances are in agreement with usual bonds of their kinds ( $\mathrm{C}-\mathrm{Br}: 1.79 \AA \AA \mathrm{C} \equiv \mathrm{C}: 1.19 \AA \AA \mathrm{C} \equiv \mathrm{N}: 1.15 \AA$ ). The structure of compound 10 confirmed the $E$-configuration of the double bond. The two $\mathrm{C}-\mathrm{C}$ single bonds linked to the $\mathrm{C}=\mathrm{C}$ double bond are significantly shorter than usual C-C single bonds: $1.44 \AA$ for the one next to the $\mathrm{C} \equiv \mathrm{C}$ triple bond and $1.41 \AA$ for the one next to the nitrile group. Likewise, the $\mathrm{C}=\mathrm{C}$ double bond is slightly longer than usual: $1.37 \AA$. These distances are most probably due to the push-pull structure of the edifice with one electron-withdrawing group (the nitrile) conjugated to two electron-donating groups (the amine and the $\mathrm{C} \equiv \mathrm{C}$ triple bond).

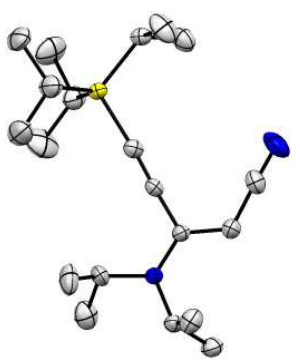

Figure 1 X-ray structures of compounds $\mathbf{2}$ (left) and $\mathbf{1 0}$ (right). Thermal ellipsoids are drawn with $50 \%$ probability. Concerning compound $\mathbf{1 0}, \mathrm{H}$-atoms were omitted for clarity. ${ }^{17}$

In order to rationalize the formation of enynenitriles from such conditions, we postulate that the first step is the addition of the amine. This step would direct the $E$ configuration of the CC double bond for steric reasons as indicated below. Then, a Sonogashira coupling can happen for coupling the alkyne (scheme 2).

The $E$-selectivity may be explained by steric arguments: the diisopropylamine (and to a lesser extent the diethylamine) group hinders the presence of the cyano group, which is bigger than a proton. Therefore, the $E$-isomer should be more stable than the $Z$-isomer. This statement was corroborated by G4MP2 high-level ab initio ${ }^{18}$ and B3LYP/6-31+G(d,p) ${ }^{19}$ DFT calculations using simple acetylene or phenylacetylene and diisopropylamine as substituents in the gas phase or in THF. In each case, the difference of free energy between the two isomers was significant (above $10 \mathrm{~kJ}^{\mathrm{mol}}{ }^{-1}$ ) in the gas phase and was even reinforced in THF,

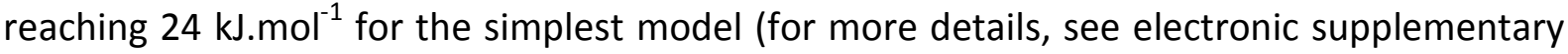
information).

We cannot rule out the fact that an ynamine has intermediately been formed as we demonstrated with $\mathrm{BrC}_{5} \mathrm{~N}{ }^{7}$ Nevertheless, all attempts to synthesize the ynamine from $\mathrm{BrC}_{3} \mathrm{~N}$ and diisopropylamine were unsuccessful so far. An alternative mechanism that would consist in first a Cadiot-Chodkiewicz coupling between the two acetylenic compounds (to yield a 
conjugated diyne) followed by the 1,4-addition of the amine is less likely. Indeed, we showed that the 1,6-addition of an amine to conjugated cyanobutadiyne derivatives is generally more favorable than the 1,4 -addition. ${ }^{20}$ However, we never detected any traces of a product coming from a 1,6-addition in these experiments, which tends to rule out this kind of mechanism.

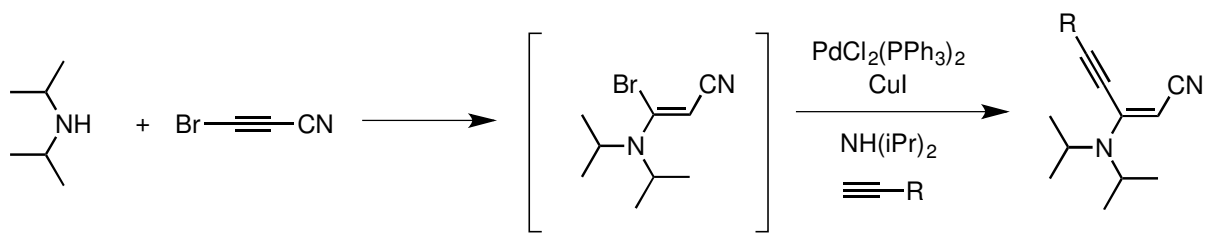

Scheme 2 Postulated sequence of reactions leading to the formation of enynenitriles.

To conclude, this article describes an original method to synthesize 1,3-enynenitriles in one-step from acetylenic compounds in a stereoselective manner, which opens a new way towards 1,3-enynes. Moreover, to the best of our knowledge, the reactivity of $\mathrm{BrC}_{3} \mathrm{~N}$, which synthesis has been reported for more than 50 years ago, had never been investigated, except recently for generating $\mathrm{C}_{3} \mathrm{~N}$ radical, $\mathrm{C}_{3} \mathrm{~N}^{-}$anion and metal acetylides in the gas phase. ${ }^{21}$ Therefore, $\mathrm{BrC}_{3} \mathrm{~N}$ appears as a promising precursor of novel molecules that could interest the field of optoelectronics.

\section{Experimental section}

\section{General}

Reactions were monitored by thin layer chromatography (Merck TLC silica gel $60 \mathrm{~F}_{254}$ on aluminum sheets) and visualized under UV irradiation at $254 \mathrm{~nm}$ or $\mathrm{KMnO}_{4}$ staining solution. Compounds were purified by column chromatography using Geduran ${ }^{\circledR}$ silica gel 60 (0.040$0.063 \mathrm{~nm}$ ). NMR spectra were recorded on Bruker Avance $400 \mathrm{MHz}$ spectrometer. Spectra were recorded in deuterochloroform referenced to $\mathrm{CHCl}_{3}\left({ }^{1} \mathrm{H}, 7.26 \mathrm{ppm}\right)$ or $\mathrm{CDCl}_{3}\left({ }^{13} \mathrm{C}, 77.2\right.$ ppm). Chemical shifts $(\delta)$ are reported in ppm and coupling contants $(J)$ are reported in Hertz. The following abbreviations are used to describe multiplicity: s-singlet, $d$-doublet, t-triplet, qquartet, quin-quintuplet, sept-septet and m-multiplet. HRMS experiments were carried out on a Waters Q-Tof 2 spectrometer.

Single crystal diffraction data were collected at low temperature on a D8 Venture Bruker AXS CMOS diffractometer with multilayers monochromatized Mo $\mathrm{K}$ a radiation. Structure was solved by dual-space algorithm using SHELXT program. ${ }^{22}$ All non-hydrogen atoms were refined anisotropically by the full-matrix least-squares techniques using the program SHELXL$2014 .^{23}$ Hydrogen atoms were located geometrically and treated using a riding model with isotropic atomic displacement parameter constrained to the equivalent adp of the bonded carbon atom.

Bromocyanoacetylene (2). Bromocyanoacetylene 2 was synthesized according to a published procedure ${ }^{10}$ Crystal data (CCDC \#1516110): $\mathrm{C}_{3} \mathrm{BrN}, \mathrm{M}=129.95 \mathrm{~g} \cdot \mathrm{mol}^{-1}, \mathrm{~T}=150 \mathrm{~K}$, monoclinic, space group $=P 21 / m, a=5.0950(10) \AA, b=6.1734(13) \AA, c=6.2035(14) \AA, \alpha=$ $90^{\circ}, \beta=95.735(9)^{\circ}, \gamma=90^{\circ}, V=194.14(7) \AA^{3}, Z=2, D c=2.223 \mathrm{~g} \mathrm{~cm}^{-3}$, absorption coefficient $=10.357 \mathrm{~mm}^{-1}, \mathrm{~F}(000)=120$, reflections collected $=1670$, independent reflections $=486$ (Rint $=0.0407)$, data/restraints $/$ parameters $=486 / 0 / 31$. Final $R$ indices $(I>2 \sigma): R 1=0.0289$. $R$ indices (all data): $w R 2=0.0719$, goodness-of-fit on $F^{2}$ of 1.217 . 
General procedure for preparation of enynes 5 to 23. A solution of 1-bromo-1propynenitrile in $10 \mathrm{~mL}$ of THF $(0.2 \mathrm{M})$ was placed into a two-neck flask under nitrogen atmosphere. The acetylene ( 2 equiv), $\mathrm{PdCl}_{2}\left(\mathrm{PPh}_{3}\right)_{2}$ (0.1 equiv) and the amine (5 equiv) were added quickly one after the other. The solution was degassed during $10 \mathrm{~min}$ of stirring and then $\mathrm{Cul}$ ( 0.1 equiv) was added. After $17 \mathrm{~h}$ at r.t., the solvent was evaporated under vacuum. The residue was purified by column chromatography.

(E)-3-(diethylamino)-5-phenylpent-2-en-4-ynenitrile (5). The general procedure was followed with phenylacetylene and diethylamine. The residue was purified by chromatography $\left(\mathrm{SiO}_{2}, n\right.$-pentane/ $\mathrm{CH}_{2} \mathrm{Cl}_{2}$ from $1 / 0$ to $\left.0 / 1\right)$. Compound 5 was obtained as orange oil in $34 \%$ yield (126.7 mg / $0.57 \mathrm{mmol}) .{ }^{1} \mathbf{H}$ NMR $400 \mathrm{MHz}^{\mathrm{CDCl}}{ }_{3} \delta(\mathrm{ppm}): 7.56(\mathrm{~m}$, $2 \mathrm{H}), 7.26-7.36(\mathrm{~m}, 3 \mathrm{H}), 4.09(\mathrm{~s}, 1 \mathrm{H}), 3.37\left(\mathrm{q},{ }^{3} \mathrm{~J}_{\mathrm{HH}}=7.1 \mathrm{~Hz}, 4 \mathrm{H}\right), 1.18\left(\mathrm{t},{ }^{3} \mathrm{~J}_{\mathrm{HH}}=7.1 \mathrm{~Hz}, 6 \mathrm{H}\right)-{ }^{13} \mathrm{C}$ NMR $100 \mathrm{MHz} \mathrm{CDCl}_{3} \delta$ (ppm): 144.8, 132.1, 129.7, 128.5, 121.8, 121.2, 97.5, 81.6, 67.0, 45.5, 12.8. HRMS (ESI) $\mathrm{m} / \mathrm{z}$ calculated $[\mathrm{M}+\mathrm{Na}]^{+} 247.1211$, found 247.1210 .

(E)-3-(diisopropylamino)-5-phenylpent-2-en-4-ynenitrile (6). The general procedure was followed with phenylacetylene and diisopropylamine. Compound 6 was obtained as orange oil in $82 \%$ yield (307.5 mg / $1.48 \mathrm{mmol}) .{ }^{1} \mathrm{H}$ NMR $400 \mathrm{MHz} \mathrm{CDCl}_{3} \delta(\mathrm{ppm}): 7.59(\mathrm{~m}, 2 \mathrm{H}), 7.35$ $(\mathrm{m}, 3 \mathrm{H}), 4.24(\mathrm{~s}, 1 \mathrm{H}), 3.97\left(\mathrm{sept},{ }^{3} \mathrm{~J}_{\mathrm{HH}}=6.8 \mathrm{~Hz}, 2 \mathrm{H}\right), 1.27\left(\mathrm{~d},{ }^{3} \mathrm{~J}_{\mathrm{HH}}=6.9 \mathrm{~Hz}, 12 \mathrm{H}\right)-{ }^{13} \mathrm{C}$ NMR 100 $\mathrm{MHz} \mathrm{CDCl}_{3} \delta(\mathrm{ppm}): 142.9,131.3,129.2,128.0,121.4,120.9,97.1,82.9,68.9,48.9,19.8$. HRMS (ESI) $\mathrm{m} / \mathrm{z}$ calculated $[\mathrm{M}+\mathrm{Na}]^{+}$275.1524, found 275.1526 .

(E)-3-(bis((R)-1-phenylethyl)amino)-5-phenylpent-2-en-4-ynenitrile (7). The general procedure was followed with phenylacetylene and $(R)$-bis $((R)$-1-phenylethyl)amine. Compound 7 was obtained as a brown oil in $42 \%$ yield ( $139.3 \mathrm{mg} / 0.36 \mathrm{mmol}) .{ }^{1} \mathbf{H}$ NMR 400 $\mathrm{MHz} \mathrm{CDCl}_{3} \delta(\mathrm{ppm}): 7.60-7.56(\mathrm{~m}, 2 \mathrm{H}), 7.45-7.33(\mathrm{~m}, 3 \mathrm{H}), 7.32-7.16(\mathrm{~m}, 10 \mathrm{H}), 5.37(\mathrm{q}$, $\left.{ }^{3} \mathrm{~J}_{\mathrm{HH}}=7.2 \mathrm{~Hz}, 2 \mathrm{H}\right), 3.95(\mathrm{~s}, 1 \mathrm{H}), 1.80\left(\mathrm{~d},{ }^{3} \mathrm{~J}_{\mathrm{HH}}=7.1 \mathrm{~Hz}, 6 \mathrm{H}\right)-{ }^{13} \mathrm{C} \mathbf{N M R} 100 \mathrm{MHz} \mathrm{CDCl}_{3} \delta(\mathrm{ppm})$ : 143.0, 139.4, 132.6, 132.2, 129.8, 128.6, 128.6, 127.7, 127.1, 121.2, 98.8, 83.1, 73.1, 56.6, 17.1. HRMS (ESI) $\mathrm{m} / \mathrm{z}$ calculated $[\mathrm{M}+\mathrm{Na}]^{+} 399.1832$, found 399.1833 .

(E)-3-(diisopropylamino)-5-(trimethylsilyl)pent-2-en-4-ynenitrile (8). The general procedure was followed with trimethylsilylacetylene and diisopropylamine. Compound 8 was obtained as yellow oil in $60 \%$ yield $(244.3 \mathrm{mg} / 0.99 \mathrm{mmol}) .{ }^{1} \mathrm{H}$ NMR $400 \mathrm{MHz} \mathrm{CDCl}_{3}$ $\delta(\mathrm{ppm}): 4.19(\mathrm{~s}, 1 \mathrm{H}), 3.97\left(\mathrm{sept},{ }^{3} \mathrm{~J}_{\mathrm{HH}}=7.0 \mathrm{~Hz}, 2 \mathrm{H}\right), 1.25\left(\mathrm{~d},{ }^{3} \mathrm{~J}_{\mathrm{HH}}=7.0 \mathrm{~Hz}, 12 \mathrm{H}\right), 0.25(\mathrm{~s}, 9 \mathrm{H})-$ ${ }^{13} \mathrm{C}$ NMR $100 \mathrm{MHz} C D C l_{3} \delta$ (ppm): 143.7, 122.2, 105.4, 98.3, 70.9, 50.0, 20.9, 0.0. HRMS (ESI) $\mathrm{m} / \mathrm{z}$ calculated $[\mathrm{M}+\mathrm{Na}]^{+} 271.1607$, found 271.1608 .

(E)-3-(diisopropylamino)-5-(triethylsilyl)pent-2-en-4-ynenitrile (9). The general procedure was followed with triethylsilylacetylene and diisopropylamine. The residue was purified by chromatography $\left(\mathrm{SiO}_{2}, \mathrm{CH}_{2} \mathrm{Cl}_{2}\right)$. Compound 9 was obtained as a dark oil in $25 \%$ yield (40.7 mg / $0.14 \mathrm{mmol}) .{ }^{1} \mathrm{H}$ NMR $400 \mathrm{MHz} \mathrm{CDCl}_{3} \delta(\mathrm{ppm}): 4.20(\mathrm{~s}, 1 \mathrm{H}), 3.98\left(\mathrm{sept},{ }^{3} \mathrm{~J}_{\mathrm{HH}}=\right.$ $6.9 \mathrm{~Hz}, 2 \mathrm{H}), 1.26\left(\mathrm{~d},{ }^{3} \mathrm{~J}_{\mathrm{HH}}=6.9 \mathrm{~Hz}, 12 \mathrm{H}\right), 1.03\left(\mathrm{t},{ }^{3} \mathrm{~J}_{\mathrm{HH}}=7.9 \mathrm{~Hz}, 9 \mathrm{H}\right), 0.69\left(\mathrm{q},{ }^{3} \mathrm{~J}_{\mathrm{HH}}=7.9 \mathrm{~Hz}, 6 \mathrm{H}\right)-$ ${ }^{13} \mathrm{C} \mathrm{NMR} 100 \mathrm{MHz} \mathrm{CDCl}_{3} \delta$ (ppm): 143.2, 121.6, 103.0, 98.7, 70.4, 49.4, 20.4, 7.5, 4.2. HRMS (ESI) $\mathrm{m} / \mathrm{z}$ calculated $[\mathrm{M}+\mathrm{Na}]^{+} 313.2071$, found 313.2074 .

(E)-3-(diisopropylamino)-5-(triisopropylsilyl)pent-2-en-4-ynenitrile (10). The general procedure was followed with triisopropylsilylacetylene and diisopropylamine. Compound 10 was obtained as a beige solid in $23 \%$ yield (128.2 mg / $0.44 \mathrm{mmol}) .{ }^{1} \mathbf{H}$ NMR $400 \mathrm{MHz} \mathrm{CDCl}_{3}$ $\delta(\mathrm{ppm}): 4.18(\mathrm{~s}, 1 \mathrm{H}), 4.03\left(\mathrm{sept},{ }^{3} \mathrm{~J}_{\mathrm{HH}}=6.8 \mathrm{~Hz}, 2 \mathrm{H}\right), 1.24\left(\mathrm{~d},{ }^{3} \mathrm{~J}_{\mathrm{HH}}=6.9 \mathrm{~Hz}, 12 \mathrm{H}\right), 1.11(\mathrm{~m}, 21 \mathrm{H})-$

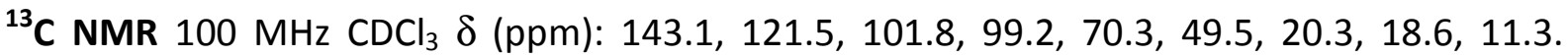
HRMS (ESI) $\mathrm{m} / \mathrm{z}$ calculated $[\mathrm{M}+\mathrm{Na}]^{+} 355.2546$, found 355.2546 . Crystal data (CCDC $\# 1485944): \mathrm{C}_{20} \mathrm{H}_{36} \mathrm{~N}_{2} \mathrm{Si}, \mathrm{M}=332.60 \mathrm{~g} \cdot \mathrm{mol}^{-1}, \mathrm{~T}=150 \mathrm{~K}$, orthorhombic, space group = $\mathrm{Pbca}, \mathrm{a}=$ 15.4294(14) $\AA, b=15.5710(14) \AA, c=17.8506(15) \AA, \alpha=90^{\circ}, \beta=90^{\circ}, \gamma=90^{\circ}, V=4288.6(7)$ 
$\AA^{3}, Z=8, D c=1.030 \mathrm{~g} \mathrm{~cm}^{-3}$, absorption coefficient $=0.112 \mathrm{~mm}^{-1}, F(000)=1472$, reflections collected $=32096$, independent reflections $=4912$ (Rint $=0.0887$ ), data $/$ restraints $/$ parameters $=4912 / 0 / 218$. Final $R$ indices $(I>2 \sigma): R 1=0.0658$. $R$ indices (all data): $w R 2=$ 0.1633 , goodness-of-fit on $F^{2}$ of 1.023 .

(E)-3-(diisopropylamino)-7-(triisopropylsilyl)hepta-2-en-4,6-diynenitrile (11). The general procedure was followed with triisopropylsilyl-1,3-butadiyne ${ }^{7}$ and diisopropylamine. Compound 11 was obtained as orange oil in $75 \%$ yield ( $545.5 \mathrm{mg} / 1.52 \mathrm{mmol}$ ). ${ }^{1} \mathbf{H}$ NMR 400 $\mathrm{MHz} \mathrm{CDCl}_{3} \delta(\mathrm{ppm}): 4.27(\mathrm{~s}, 1 \mathrm{H}), 3.90\left(\mathrm{sept}^{3} \mathrm{~J}_{\mathrm{HH}}=6.7 \mathrm{~Hz}, 2 \mathrm{H}\right), 1.20\left(\mathrm{~d},{ }^{3} \mathrm{~J}_{\mathrm{HH}}=6.7 \mathrm{~Hz}, 12 \mathrm{H}\right)$, $1.03(\mathrm{~m}, 21 \mathrm{H})-{ }^{13} \mathrm{C}$ NMR $100 \mathrm{MHz} \mathrm{CDCl}_{3} \delta$ (ppm): 141.7, 120.7, 92.4, 88.0, 82.0, 72.0, 67.8, 49.6, 20.1, 18.4, 11.1. HRMS (ESI) $\mathrm{m} / \mathrm{z}$ calculated [M+Na] ${ }^{+} 379.2545$, found 379.2542 .

(E)-3-(diisopropylamino)undec-2-en-4-ynenitrile (12). The general procedure was followed with 1-octyne and diisopropylamine. Compound $\mathbf{1 2}$ was obtained as colorless oil in $55 \%$ yield (213.3 mg / $0.82 \mathrm{mmol}) .{ }^{1} \mathrm{H}$ NMR $400 \mathrm{MHz} \mathrm{CDCl}_{3} \delta(\mathrm{ppm}): 4.05(\mathrm{~s}, 1 \mathrm{H}), 3.91$ (sept, ${ }^{3} \mathrm{~J}_{\mathrm{HH}}=6.8$ $\mathrm{Hz}, 2 \mathrm{H}$ ), $2.35\left(\mathrm{t},{ }^{3} \mathrm{~J}_{\mathrm{HH}}=7.1 \mathrm{~Hz}, 2 \mathrm{H}\right.$ ), 1.52 (quin, ${ }^{3} \mathrm{~J}_{\mathrm{HH}}=7.8 \mathrm{~Hz}, 2 \mathrm{H}$ ), 1.36 (quin, ${ }^{3} \mathrm{~J}_{\mathrm{HH}}=13.7 \mathrm{~Hz}, 2 \mathrm{H}$ ), $1.22(\mathrm{~m}, 4 \mathrm{H}), 1.17\left(\mathrm{~d},{ }^{3} \mathrm{~J}_{\mathrm{HH}}=6.9 \mathrm{~Hz}, 12 \mathrm{H}\right), 0.80\left(\mathrm{t},{ }^{3} \mathrm{~J}_{\mathrm{HH}}=7.0 \mathrm{~Hz}, 3 \mathrm{H}\right)-{ }^{13} \mathrm{C} \mathrm{NMR} 100 \mathrm{MHz} \mathrm{CDCl}_{3}$ $\delta$ (ppm): 143.9, 122.0, 100.0, 74.6, 68.3, 49.1, 31.1, 28.5, 27.8, 22.4, 20.1, 19.3, 13.9. HRMS (ESI) $\mathrm{m} / \mathrm{z}$ calculated $[\mathrm{M}+\mathrm{Na}]^{+} 283.2150$, found 283.2152 .

(E)-3-(diisopropylamino)-5-(p-tolyl)pent-2-en-4-ynenitrile (14). The general procedure was followed with 4-ethynyltoluene and diispropylamine. Compound $\mathbf{1 4}$ was obtained as an orange oil in $57 \%$ yield (95.4 mg / $0.36 \mathrm{mmol}) .{ }^{1} \mathbf{H}$ NMR $400 \mathrm{MHz} \mathrm{CDCl}_{3} \delta(\mathrm{ppm}): 7.49-7.45$ $(\mathrm{m}, 2 \mathrm{H}), 7.19-7.13(\mathrm{~m}, 2 \mathrm{H}), 4.24(\mathrm{~s}, 1 \mathrm{H}), 4.00\left(\mathrm{sept},{ }^{3} \mathrm{~J}_{\mathrm{HH}}=6.9 \mathrm{~Hz}, 2 \mathrm{H}\right), 2.36(\mathrm{~s}, 3 \mathrm{H}), 1.31(\mathrm{~d}$, $\left.{ }^{3} \mathrm{~J}_{\mathrm{HH}}=6.9 \mathrm{~Hz}, 12 \mathrm{H}\right){ }^{13} \mathrm{C} \mathrm{NMR} 100 \mathrm{MHz} \mathrm{CDCl}_{3} \delta(\mathrm{ppm}): 143.8,140.1,131.9,129.3,122.1,118.5$, 98.2, 82.9, 69.4, 49.5, 21.7, 20.5. HRMS (ESI) $\mathrm{m} / \mathrm{z}$ calculated $[\mathrm{M}+\mathrm{Na}]^{+} 289.1675$, found 289.1676.

Methyl-(E)-4-(4-cyano-3-(diisopropylamino)but-3-en-1-yn-1-yl)benzoate (17). The general procedure was followed with methyl 4-ethynylbenzoate and diispropylamine. The residue was purified by chromatography $\left(\mathrm{SiO}_{2}, \mathrm{CH}_{2} \mathrm{Cl}_{2} / \mathrm{MeOH}=1: 0\right.$ to 99:1). Compound 17 was obtained as an orange oil in $55 \%$ yield $(118 \mathrm{mg} / 0.38 \mathrm{mmol}) .{ }^{1} \mathrm{H} ~ \mathrm{NMR} 400 \mathrm{MHz} \mathrm{CDCl}_{3} \delta$ (ppm): $8.05-7.94(\mathrm{~m}, 2 \mathrm{H}), 7.65-7.58(\mathrm{~m}, 2 \mathrm{H}), 4.28(\mathrm{~s}, 1 \mathrm{H}), 3.97\left(\mathrm{sept},{ }^{3} \mathrm{~J}_{\mathrm{HH}}=6.9 \mathrm{~Hz}, 2 \mathrm{H}\right)$, $3.89(\mathrm{~s}, 3 \mathrm{H}), 1.29\left(\mathrm{~d},{ }^{3} \mathrm{~J}_{\mathrm{HH}}=6.9 \mathrm{~Hz}, 12 \mathrm{H}\right){ }^{13}{ }^{13} \mathrm{CNMR} 100 \mathrm{MHz} \mathrm{CDCl}_{3} \delta(\mathrm{ppm}): 166.3,143.0$, 131.8, 130.7, 129.6, 126.0, 121.7, 96.5, 85.7, 70.5, 52.4, 49.6, 20.4. HRMS (ESI) $\mathrm{m} / \mathrm{z}$ calculated $[\mathrm{M}+\mathrm{Na}]^{+} 333.1574$, found 333.1574 .

(E)-3-(diisopropylamino)-5-(4-(trifluoromethyl)phenyl)pent-2-en-4-ynenitrile (18). The general procedure was followed with 4-trifluoromethylphenylacetylene and diisopropylamine. Compound 18 was obtained as a brown oil in $82 \%$ yield $(239.4 \mathrm{mg} / 0.74$ mmol). ${ }^{1} \mathbf{H}$ NMR $400 \mathrm{MHz} \mathrm{CDCl}_{3} \delta(\mathrm{ppm}): 7.77-7.56(\mathrm{~m}, 4 \mathrm{H}), 4.32(\mathrm{~s}, 1 \mathrm{H}), 4.01\left(\mathrm{sept},{ }^{3} \mathrm{~J}_{\mathrm{HH}}=\right.$ $6.9 \mathrm{~Hz}, 2 \mathrm{H}), 1.33\left(\mathrm{~d},{ }^{3} \mathrm{~J}_{\mathrm{HH}}=6.9 \mathrm{~Hz}, 12 \mathrm{H}\right)-{ }^{13} \mathrm{C}$ NMR $100 \mathrm{MHz}^{-C_{C C l}} \delta(\mathrm{ppm}): 143.1,135.3$, $132.9,132.3,131.5,131.2,125.6,125.6,125.5,125.5,125.3,121.8,96.1,85.4,70.7,49.7$, 20.6. HRMS (ESI) $\mathrm{m} / \mathrm{z}$ calculated $[\mathrm{M}+\mathrm{Na}]^{+} 343.1392$, found 343.1391 .

(E)-3-(diisopropylamino)-1- $\mathrm{N}$-benzyl-4-methylbenzenesulfonamidepent-2-en-4-ynenitrile (20). The general procedure was followed with N-benzyl-N-ethynyl-4methylbenzenesulfonamide ${ }^{13}$ and diisopropylamine. Compound 20 was obtained as a colorless oil in 23\% yield (64 mg / $0.15 \mathrm{mmol}) .{ }^{1} \mathrm{H}$ NMR $400 \mathrm{MHz} \mathrm{CDCl}_{3} \delta(\mathrm{ppm}): 7.71(\mathrm{~m}, 2 \mathrm{H})$, $7.36(\mathrm{~m}, 2 \mathrm{H}), 7.24(\mathrm{~m}, 5 \mathrm{H}, \mathrm{Hm}), 4.54(\mathrm{~s}, 2 \mathrm{H}), 3.97(\mathrm{~s}, 1 \mathrm{H}), 3.76\left(\mathrm{sept},{ }^{3} \mathrm{~J}_{\mathrm{HH}}=6.9 \mathrm{~Hz}, 2 \mathrm{H}\right), 2.36(\mathrm{~s}$, $3 \mathrm{H}), 1.08\left(\mathrm{~d},{ }^{3} \mathrm{~J}_{\mathrm{HH}}=6.9 \mathrm{~Hz}, 12 \mathrm{H}\right)-{ }^{13} \mathrm{C} \mathrm{NMR} 100 \mathrm{MHz} \mathrm{CDCl}_{3} \delta(\mathrm{ppm}): 145.2,143.5,134.8,134.3$, $130.1,129.2,128.7,128.5,127.8,122.5,90.9,66.5,55.8,49.6,21.8,20.2$. HRMS (ESI) $\mathrm{m} / \mathrm{z}$ calculated $[\mathrm{M}+\mathrm{Na}]^{+} 458.1873$, found 458.1874 . 
(E)-3-(diisopropylamino)-5-(4-methoxyphenyl)pent-2-en-4-ynenitrile (21). The general procedure was followed with 4-ethynylanisole and diisopropylamine. Compound $\mathbf{2 1}$ was obtained as an orange oil in $66 \%$ yield $(96.2 \mathrm{mg} / 0.34 \mathrm{mmol}) .{ }^{1} \mathbf{H}$ NMR $400 \mathrm{MHz} \mathrm{CDCl}_{3} \delta$ (ppm): $7.55-7.50(\mathrm{~m}, 2 \mathrm{H}), 6.90-6.84(\mathrm{~m}, 2 \mathrm{H}), 4.22(\mathrm{~s}, 1 \mathrm{H}), 4.01\left(\mathrm{sept},{ }^{3} \mathrm{~J}_{\mathrm{HH}}=6.9 \mathrm{~Hz}, 2 \mathrm{H}\right)$, $3.82(\mathrm{~s}, 3 \mathrm{H}), 1.31\left(\mathrm{~d},{ }^{3} \mathrm{~J}_{\mathrm{HH}}=6.9 \mathrm{~Hz}, 12 \mathrm{H}\right)-{ }^{13} \mathrm{C}$ NMR $100 \mathrm{MHz} \mathrm{CDCl}_{3} \delta(\mathrm{ppm}): 160.8,144.1$, 133.7, 122.3, 114.3, 113.6, 98.4, 82.5, 69.0, 55.5, 49.5, 20.6. HRMS (ESI) m/z calculated $[\mathrm{M}+\mathrm{Na}]^{+} 305.1624$, found 305.1620 .

(E)-3-(diisopropylamino)-5-ferrocen-2-en-4-ynenitrile (22). The general procedure was followed with ethynylferrocene and diisopropylamine. Compound $\mathbf{2 2}$ was obtained as red solid in $80 \%$ yield $(431.5 \mathrm{mg} / 1.20 \mathrm{mmol}) .{ }^{1} \mathbf{H}$ NMR $400 \mathrm{MHz} \mathrm{CDCl}_{3} \delta(\mathrm{ppm}): 4.52\left(\mathrm{t},{ }^{3} \mathrm{~J}_{\mathrm{HH}}=2.0\right.$ $\mathrm{Hz}, 2 \mathrm{H}), 4.28(\mathrm{~s}, 5 \mathrm{H}), 4.26\left(\mathrm{t},{ }^{3} \mathrm{~J}_{\mathrm{HH}}=2.0 \mathrm{~Hz}, 2 \mathrm{H}\right), 4.16(\mathrm{~s}, 1 \mathrm{H}), 3.97\left(\mathrm{sept},{ }^{3} \mathrm{~J}_{\mathrm{HH}}=7.0 \mathrm{~Hz}, 2 \mathrm{H}\right), 1.25$ $\left(\mathrm{d},{ }^{3} \mathrm{~J}_{\mathrm{HH}}=7.0 \mathrm{~Hz}, 12 \mathrm{H}\right){ }^{13}{ }^{13} \mathrm{C}$ NMR $100 \mathrm{MHz} \mathrm{CDCl}_{3} \delta(\mathrm{ppm}): 143.8,122.1,98.1,79.5,71.6,70.1$, 69.5, 68.4, 62.6, 49.2, 20.4. HRMS (ESI) $\mathrm{m} / \mathrm{z}$ calculated [M+Na] ${ }^{+} 383.1187$, found 383.1181 .

(E)-3-(diisopropylamino)-5-(4'-ethynyl-[1,1'-biphenyl]-4-yl)pent-2-en-4-ynenitrile (23). The general procedure was followed with 4,4'-diethynylbiphenyl ${ }^{14}$ and diisopropylamine. Compound 23 was obtained as beige solid in $44 \%$ yield ( $123.1 \mathrm{mg} / 0.35 \mathrm{mmol}) .{ }^{1} \mathbf{H}$ NMR 400 $\mathrm{MHz} C D C l_{3} \delta(\mathrm{ppm}): 7.60(\mathrm{~m}, 2 \mathrm{H}), 7.52(\mathrm{~m}, 2 \mathrm{H}), 7.49,(\mathrm{~m}, 4 \mathrm{H}), 4.22(\mathrm{~s}, 1 \mathrm{H}), 3.95\left(\mathrm{sept},{ }^{3} \mathrm{~J}_{\mathrm{HH}}=\right.$ $6.9 \mathrm{~Hz}, 2 \mathrm{H}), 3.08(\mathrm{~s}, 1 \mathrm{H}), 1.26\left(\mathrm{~d},{ }^{3} \mathrm{~J}_{\mathrm{HH}}=7.0 \mathrm{~Hz}, 12 \mathrm{H}\right)-{ }^{13} \mathrm{C} \mathrm{NMR} 100 \mathrm{MHz} \mathrm{CDCl}_{3} \delta$ (ppm): 143.6, $141.4,140.5,132.8,132.5,127.2,127.0,122.1,121.8,120.9,97.7,84.3,83.5,78.3,69.9$, 53.6, 20.6, 13.1. HRMS (ESI) $\mathrm{m} / \mathrm{z}$ calculated $[\mathrm{M}+\mathrm{Na}]^{+} 375.1837$, found 375.1839 .

(2E,8E)-3,8-bis(diisopropylamino)deca-2,8-dien-4,6-diynedinitrile (24). A solution of tetra- $n$-butylammonium fluoride $(1.0 \mathrm{M}$ in THF, $0.32 \mathrm{mmol})$ in dry THF $(5 \mathrm{~mL})$ was added over $2 \mathrm{~h}$ via syringe to a stirred solution of anhydrous $\mathrm{Cu}(\mathrm{OAc})_{2}(175,4 \mathrm{mg}, 0,96 \mathrm{mmol})$ and compound 10 (107,3 $\mathrm{mg}, 0.32 \mathrm{mmol})$ in a mixture of dry pyridine / diethyl ether $(3: 1,97 \mathrm{~mL})$. The blue solution became progressively emerald green as the tetra- $n$-butylammonium fluoride solution was added. Once addition was complete, the solution was poured into diethyl ether and aqueous $\mathrm{HCl}(1 \mathrm{M})$. The organic phase was washed with aqueous $\mathrm{HCl}(1 \mathrm{M})$ until all the pyridine was removed. Then the organic phase was dried and concentrated to yield a crude solid, which was further purified by chromatography $\left(\mathrm{SiO}_{2}, \mathrm{CH}_{2} \mathrm{Cl}_{2}\right)$ to yield compound 24 as an orange oil in $10 \%$ yield $(11.1 \mathrm{mg} / 0.031 \mathrm{mmol}) .{ }^{1} \mathbf{H}$ NMR $400 \mathrm{MHz} \mathrm{CDCl}_{3}$ $\delta(\mathrm{ppm}): 4.37(\mathrm{~s}, 2 \mathrm{H}), 3.97\left(\mathrm{sept},{ }^{3} \mathrm{~J}_{\mathrm{HH}}=6.7 \mathrm{~Hz}, 4 \mathrm{H}\right), 1.27\left(\mathrm{~d},{ }^{3} \mathrm{~J}_{\mathrm{HH}}=6.9 \mathrm{~Hz}, 24 \mathrm{H}\right){ }^{13} \mathrm{C}$ NMR 100 $\mathrm{MHz}, \mathrm{CDCl}_{3} \delta$ (ppm) : 141.4, 120.8, 80.3, 77.3, 72.9, 50.1, 20.4. HRMS (ESI) m/z calculated $[\mathrm{M}+\mathrm{Na}]^{+} 373.2363$ found 373.2363 .

\section{Acknowledgments}

This study is a part of the project ANR-13-BS05-0008 IMOLABS from the Agence Nationale pour la Recherche. We also thank the CNES (Centre National d'Etudes Spatiales) and the Programme National Physique et Chimie du Milieu Interstellaire (PCMI) of CNRS/INSU with INC/INP co-funded by CEA and CNES for their financial support.

\section{References}

1 (a) N. Zein, A. M. Sinha, W. J. McGahren and G. A. Ellestad, Science, 1988, 240, 11981201; (b) A. Rudi, M. Schleyer and Y. Kashman, J. Nat. Prod., 2000, 63, 1434-1436; (c) S. L. Iverson and J. P. Uetrecht, Chem. Res. Toxicol., 2001, 14, 175-181; (d) R. E. Martin and F. 
Diederich, Angew. Chem. Int. Ed., 1999, 38, 1350-1377.

2 E.-i. Negishi and L. Anastasia, Chem. Rev., 2003, 103, 1979-2017.

3 (a) X. Lu, X. Huang and S. Ma, Tetrahedron Lett., 1992, 33, 2535-2538; (b) E.-i. Negishi, M. Qian, F. Zeng, L. Anastasia and D. Babinski, Org. Lett., 2003, 5, 1597-1600; (c) C. Wang T. Tobrman, Z. Xu and E.-i. Negishi, Org. Lett., 2009, 11, 4092-4095; (d) B. C. Ranu and K. Chattopadhyay, Org. Lett, 2007, 9, 2409-2412; (e) R. Takeuchi, K. Tanabe and S. Tanaka, J. Org. Chem., 2000, 65, 1558-1561.

4 (a) M. Hohmann and N. Krause, Chem. Ber., 1995, 128, 851-860; (b) D. H. Grayson and S. H. O'Donnell, Arkivoc, 2003, 7, 4-14.

5 (a) Y. Nakao, Y. Hirata, M. Tanaka and T. Hiyama, Angew. Chem. Int. Ed., 2008, 47, 385-387; (b) V. Dwivedi, M.H. Babu, R. Kantb and M. S. Reddy, Chem. Commun., 2015, 51, 14996-14999; (c) C. W. Cheung and X. Hu, Chem. Eur. J., 2015, 21, $18439-18444$.

6 (a) O. Rivada-Wheelaghan, S. Chakraborty, L. J. W. Shimon, Y. Ben-David and D. Milstein, Angew. Chem. Int. Ed., 2016, 55, 6942 - 6945; (b) J. T. Danence Lee and Y. Zhao, Angew. Chem. Int. Ed., 2016, 55, 13872 -13876; (c) Q. Liang, K. M. Osten and D. Song Angew. Chem. Int. Ed. 2017, 56, 6317-6320.

7 N. Kerisit, L. Toupet, P. Larini, L. Perrin, J.-C. Guillemin and Y. Trolez, Chem. Eur. J., 2015, 21, 6042-6047.

8 D. N. Tomilin, B. Pigulski, N. Gulia, A. Arendt, L. N. Sobenina, A. I. Mikhaleva, S. Szafert and B. A. Trofimov, RSC Adv., 2015, 5, 73241-73248.

9 (a) R. A. Sanchez, J. P. Ferris and L. E. Orgel, Science, 1966, 154, 784-785; (b) T. Sasaki, T. Yoshioka and K. Shoji, J. Chem. Soc., 1969, 1086-1088; (c) G. C. Cole, H. Møllendal, B. Khater and J.-C. Guillemin, J. Phys. Chem. 2007, 111, 1259-1264; (d) M. W. Powner, B. Gerland and J. D. Sutherland, Nature, 2009, 459, 239-242.

10 E. Kloster-Jensen, Acta. Chim. Scand., 1963, 17, 1862-1865.

11 (a) M. Brunner, G. Maas and F.-G. Klärner, Helv. Chim. Acta, 2005, 1813-1825; (b) T. Kanzian, T. A. Nigst, A. Maier, S. Pichl and H. Mayr, Eur. J. Org. Chem. 2009, 6379-6385

12 A. S. Batsanov, J. C. Collings, I. J. S. Fairlamb, J. P. Holland, J. A. K. Howard, Z. Lin, T. B. Marder, A. C. Parsons, R. M. Ward and J. Zhu, J. Org. Chem., 2005, 70, 703-706.

13 (a) B. Witulski and T. Stengel, Angew. Chem. Int. Ed., 1998, 37, 489-492; (b) B. Witulski, N. Buschmann and U. Bergsträßer, Tetrahedron, 2000, 56, 8473-8480; (c) D. Brückner, Tetrahedron, 2006, 62, 3809-3814.

14 J.-X. Jiang, F. Su, A. Trewin, C. D. Wood, H.Niu, J. T. A. Jones, Y. Z. Khimyak and A. I. Cooper J. Am. Chem. Soc., 2008, 24, 7710-7720

15 M. A. Heuft, S. K. Collins, G. P. A. Yap and A. G. Fallis Org. Lett., 2011, 3, 2883-2886

16 N. Kerisit, L. Toupet, Y. Trolez and J.-C. Guillemin, Chem. Eur. J. 2013, 19, 17683 17686.

17 CCDC-1485944 (8) contains the supplementary crystallographic data for this paper. These data can be obtained free of charge from the Cambridge Crystallographic Data Centre via www.ccdc.cam.ac.uk/data request/cif.

18 L. A. Curtiss, P.C. Redfern and K. Raghavachari, J. Chem. Phys., 2007, 127, 124106.

19 (a) A. D. Becke, J. Chem. Phys., 1993, 98, 5648-5652; (b) C. Lee, W. Yang and R. G. Parr, Phys. Rev. B, 1988, 37, 785-789.

20 (a) Y. Trolez and J.-C. Guillemin, Angew. Chem. Int. Ed., 2005, 44, 7224-7226; (b) N. Kerisit, C. Rouxel, S. Colombel-Rouen, L. Toupet, J.-C. Guillemin and Y. Trolez, J. Org. Chem., 2016, 81, 3560-3567. 
21 (a) J. Bourgalais, N. Jamal-Eddine, B. Joalland, M. Capron, M. Balaganesh, J.-C. Guillemin, S. D. Le Picard, A. Faure, S. Carles and L. Biennier, Icarus, 2016, 271, 194-201; (b) C. Romanzin, E. Louarn, J. Lemaire, J. Žabka, M. Polášek, J.-C. Guillemin and C. Alcaraz, Icarus, 2016, 268, 242-252; (c) B. Joalland, N. Jamal-Eddine, J. Klos, F. Lique, Y. Trolez, J.-C. Guillemin, S. Carles and L. Biennier, J. Phys. Chem. Lett., 2016, 7, 2957-2961 ; (d) C. Cabezas, C. Barrientos, A. Largo, J.-C. Guillemin, J. Cernicharo, I. Peña and J. L. Alonso, J. Chem. Phys., 2014, 141, 104305; (e) C. Cabezas, C. Barrientos, A. Largo, J.-C. Guillemin and J. J. Alonso, Phys. Chem. Chem. Phys., 2016, 18, 28538-28547.

22 G. M. Sheldrick, Acta Cryst., 2015, A71, 3-8

23 G. M. Sheldrick, Acta Cryst., 2015, C71, 3-8 